\title{
Implementation of Guided Inquiry Learning Model on Colloid Systems to Improve Critical Thinking Ability of Students
}

\author{
*Nurul R. Arini, Sri M. Sabang \& Anang W. M. Diah \\ Program Studi Pendidikan Kimia/FKIP - Universitas Tadulako, Palu - Indonesia 94119 \\ Received 18 March 2021, Revised 16 April 2021, Accepted 19 May 2021 \\ doi: $10.22487 /$ j24775185.2021.v10.i2.pp87-92
}

\begin{abstract}
Critical thinking is the ability to solve problems through an investigation so as to produce conclusions or rational decisions. This study aimed to obtain an improvement of the critical thinking skills of students in Grade XI at SMAN 3 Palu after the implementation of the guided inquiry learning model on Colloid Systems. This study was a pre-experiment with one group pretest-posttest design. The sample was run by simple random sampling with the sample of Class XI Science 1 as the replication class $1(n=36)$ and Class XI Science 3 as the replication class $2(n=35)$. Data on students' critical thinking was taken using tests that were given before and after learning. An improvement in students' critical thinking skills in replication class 1 and replication class 2 was by 50\%. Data of students' critical thinking skills were tested using non-parametric statistical analysis, namely the Mann-Whitney test. The test results obtained the Zh value -0.076 , so $-1.96 \leq-0.076 \leq+1.96$. This result is in the reception area of $\mathrm{Ho}$, and $H_{1}$ is rejected. It means that the average score of critical thinking ability of students in replication class 1 is the same as in replication class 2. This study concluded that the implementation of the guided inquiry learning model on Colloid Systems improves the critical thinking skills of students in Grade XI at SMAN 3 Palu.
\end{abstract}

Keywords: Guided inquiry, critical thinking ability, colloid systems

\section{Introduction}

Curriculum 2013 application aims to produce productive, creative, innovative, and affective Indonesian people through strengthening attitude, knowledge, and skills. Learning design from the application of the 2013 curriculum must create interactive learning patterns and change the isolated learning system into learning by networking. The recommended learning approach and become a character from the 2013 curriculum, Scientific Approach whose application procedures have stages, namely observing, asking, trying, associating, then communicating that is expected to produce students who are qualified both in the fields of attitude, knowledge, and skills (Trianto, 2010).

Based on the 2013 curriculum, one of the hopes to be achieved in learning in high schools is that students have high-level thinking skills. Highlevel thinking ability is an important aspect of the teaching and learning process (Heong et al., 2011). High order thinking skills (HOTS) is the ability to think that is not just remembering, revealing again, and also refers without processing, but the ability to think about examining information critically, creatively, creative and able to solve problems (Aningsih, 2018). High-level thinking skills are defined as the use of thoughts more broadly to find new challenges (Rofiah et al., 2013). High-level thinking skills are very necessary related to the needs of students to solve the problems they face in everyday life. Learning requires high-level thinking skills, one of which is chemistry lessons (Pratiwi et al., 2014). According to Salbiah (2017), chemistry subjects are one of the sciences filled with natural phenomena, interesting experimental activities, applying in everyday life, and useful knowledge to understand the nature and process of the occurrence of the universe so that high-level thinking skills students become trained.

One high-level thinking ability is critical thinking skills. Critical thinking is the ability to solve problems through an investigation so as to produce rational conclusions or decisions (Wati et al., 2014). Critical thinking ability is the ability to think rationally and reflectively based on what is believed or made (Ennis, 1996). This is in line with Permendikbud No 81A in 2013 concerning the implementation of the curriculum it is stated that the needs of future competition where the ability of students needed are the ability to communicate, creative, and critical (Peraturan Menteri Pendidikan dan Kebudayaan, 2013). In fact, the critical thinking skills of students in Indonesia, especially

${ }^{*}$ Correspondence:

Nurul R. Arini

e-mail: nurulrizkiarini@gmail.com

(c) 2021 the Author(s) retain the copyright of this article. This article is published under the terms of the Creative Commons Attribution-NonCommercial-ShareAlike 4.0 International, which permits unrestricted non-commercial use, distribution, and reproduction in any medium, provided the original work is properly cited. 
high school students, still need to be improved. This is because the use of the learning model that is applied has not optimized the critical thinking skills of students (Pratiwi et al., 2014).

Based on interviews with a chemistry teacher at SMAN 3 Palu, the curriculum used in the school is the 2013 curriculum. The chemical learning process requires students to play an active role and the teacher as a mediator. The teacher provides opportunities for students to explore information from the material to be studied, one of them through discussion activities so that students are active and can express their own opinions. In fact, the learning process is not applied to all the material taught in chemistry lessons, so in a certain material, students tend to be passive, and their abilities do not develop.

The colloidal system is one of the chemical materials in class XI. Colloidal system material has characteristics, namely factual and conceptual. The colloidal system is one of the chemical concepts that explain natural phenomena and many of their applications in everyday life. This colloidal system material needs to be explored by students through active knowledge construction. So the role of the teacher is to foster independence in students by providing opportunities to act and make decisions, increase student knowledge and skills in order to make it well, provide convenience in learning by providing facilities that support and provide optimal opportunities for students. Thus, students will get used to being trained to think critically (Suyanti, 2010). The reality found in the teacher's colloidal system material only uses the lecture method and asks students to ship the material so that the ability to think students to understand the concept of material has not been trained and well developed.

Efforts to improve critical thinking skills students need the right learning model. The learning model that is expected to be able to overcome this problem is guided inquiry. Guided inquiry is one of the inquiry models that provide material or materials and problems for investigations. Students plan their own procedures to solve problems while the teacher plays a role in guiding students to carry out the procedures they plan (Banchi, 2008). Learning inquiry learning trains students to develop facts, build concepts, and draw general conclusions or theories that explain the phenomena that develop student scientific discoveries skills. In the implementation of Teacher's guided inquiry learning no longer act as information givers and recipient students, but the teacher acts as a motivator, facilitator, questioner, administrator, and director (Budiartini et al., 2013)

This paper is intended to describe the increase in critical thinking skills of students after the implementation of a guided inquiry learning model on the material of colloidal systems in class XI SMAN 3 Palu

\section{Methods}

The type of research is pre-experimental with the design of One Group Pretest-Posttest Design. This research activity was held at SMAN 3 Palu. The sample in this study was class XI MIA 1 (36 students) as a replication class 1 and XI Mia 3 (35 students) as a replication class 2 . The sampling technique was simple random sampling.

The instruments used in this study were critical thinking essay tests totaling six questions and observation sheets of teacher and student activities. The purpose of using critical thinking tests is to obtain a picture of critical thinking results. At the same time, the observation sheet of teacher activities and students aims to observe the implementation of the classroom learning process in both students and teachers.

This study's data analysis techniques include a descriptive analysis of critical thinking adapted from Ijirana (2016) by calculating the percentage of score achievements in each critical thinking category. The $\mathrm{n}$-gain test is done to see the effectiveness of the learning model used against critical thinking skills. Inferential statistical analysis uses a two-party t-test statistical test

\section{Results and Discussion}

The results of data analysis obtained during learning activities in the form of observation sheets of teacher and student activities are presented in Tables 1 and 2. Data in Table 1 shows that teacher activities in the learning process are included in the excellent category, and Table 2 shows that students' activities in learning using learning models inquiry is included in the active category.

Table 1. Teacher activity assessment results

\begin{tabular}{ccc}
\hline \multirow{2}{*}{ Meeting } & \multicolumn{2}{c}{ Average Percentage (\%) } \\
\cline { 2 - 3 } & Replication 1 & Replication 2 \\
\hline Meeting 1 & 91.25 & 92.50 \\
Meeting 2 & 95.00 & 95.00 \\
Meeting 3 & 97.50 & 97.50 \\
Total Average (\%) & 94.58 & 95.00 \\
\hline
\end{tabular}

Table 2. Student activity assessment results

\begin{tabular}{ccc}
\hline \multirow{2}{*}{ Meeting } & \multicolumn{2}{c}{ Average Percentage (\%) } \\
\cline { 2 - 3 } & Replication 1 & Replication 1 \\
\hline Meeting 1 & 86.70 & 81.70 \\
Meeting 2 & 90.00 & 93.30 \\
Meeting 3 & 93.30 & 95.00 \\
Total Average (\%) & 90.00 & 90.00 \\
\hline
\end{tabular}

\section{Pretest and posttest critical thinking analysis}

The results of the initial test data analysis (pretest) and final test (posttest) critical thinking ability of students replication class 1 and replication 2 are presented in Table 3. Based on Table 3 obtained initial test data (pretest) critical thinking ability students in replication class 1 and 2 in very low categories. This informs that students 'critical 
thinking skills in the class need to be given treatment that can improve students' critical thinking skills. One way that can be done is by applying a guided inquiry learning model. According to Suprihatiningsih (2013), every step that is passed in inquiry learning will provide opportunities for students to develop their critical thinking skills. Based on the final test data (posttest) shows that the critical thinking ability of replication class students 1 and 2 after being treated increased.

Table 3. Critical thinking skills

\begin{tabular}{lllll}
\hline \multirow{2}{*}{ Category } & \multicolumn{3}{c}{ Replication 1 } & \multicolumn{3}{c}{ Replication 2 } \\
\cline { 2 - 5 } & \multicolumn{4}{c}{ Percentage (\%) } \\
\cline { 2 - 5 } & Pretest & Posttest & Pretest & Posttest \\
\hline Very high & 0 & 29 & 0 & 20 \\
High & 0 & 33 & 0 & 40 \\
Medium & 0 & 19 & 0 & 23 \\
Low & 0 & 19 & 0 & 17 \\
\hline
\end{tabular}

The guided inquiry learning model used has 6 phases, namely asking questions or problems, making hypotheses, designing experiments, conducting experiments, collecting data and analyzing data, and drawing conclusions. According to Fardani et al. (2016) each stage of the guided inquiry learning model there are several stages that require students' thinking skills, namely the ability to think critically so that after passing through the stages of the guided inquiry learning model, students' critical thinking skills will be trained.

The first phase of the guided inquiry model is asking questions or problems. The phase of asking questions or problems, training students' critical thinking skills to ask questions, formulating questions based on the problems presented by the teacher so that students individually and in groups can use their critical thinking skills to determine the next strategy to be carried out in order to find a concept. According to Permendikbud No 81A 2013 asking questions or formulating problems helps students to form critical thoughts that are necessary to live intelligently and learn lifelong.

The second phase is making a hypothesis. In this phase, students individually or in groups present temporary answers based on the formulation of the problems they made related to the problems presented by the teacher. Students first dig up related information as much as possible through the literature. This information search will make it easier for students to provide predictive answers or hypotheses to the given problem. Making a hypothesis is the beginning of a thinking process. This is in line with Sanjaya (2009), which says that when a student can make a hypothesis and then prove the hypothesis, then he will arrive at a position that can encourage him to think further.

The third phase is designing the experiment. The teacher provides the opportunity for students to determine the steps to carry out experiments related to the problems presented to prove the hypotheses made. The teacher plays a role in guiding students in compiling the experimental steps. The next phase is conducting experiments to obtain information. The teacher guides students to get information through experiments. According to Permendikbud No 81A 2013, the activity of collecting data/information is carried out through experiments, reading sources, or literature other than textbooks.

The next phase collects and analyzes data. This phase contains student activities to collect the information needed to test the proposed hypothesis. According to Kipper \& Ruutmann (2013), various facts and information is something that plays an important role to be used in the thinking process; knowing how and having the ability to explore and use the information obtained is also equally important. Collecting data/information provides opportunities for students to inquire. Inquiry activities are intended so that students can find ideas, facts, concepts, understandings alone or in groups. Furthermore, the data obtained were analyzed to test the hypothesis. Before testing the truth of the hypothesis, students are required to use their critical thinking skills to consider whether the sources obtained are reliable or not. Students are asked to discuss it in groups and then present the results of the discussion. Students are given the opportunity to express predicted answers that are equipped with data from the problems that must be solved. Other students respond or ask questions related to what the presenter said. Students can develop their ability to ask various questions and answer a number of questions, which are part of critical thinking activities. According to Sanjaya (2009), in this inquiry phase, students can develop rational thinking skills, which means that the truth of the answers given is not only based on arguments but must be supported by data collected so that the arguments submitted can be justified.

The last phase is formulating conclusions. Students process and analyze the results of the discussions they get. Students are guided to formulate learning conclusions where it is an important concept that becomes the ultimate goal of learning using the guided inquiry model. The goal is to get accurate conclusions based on the results of discussing the predicted answers. Students in groups use their critical thinking skills in the process of drawing conclusions based on the results of hypothesis testing. According to Kipper \& Ruutmann (2013), making and assessing conclusions based on evidence is a form of critical thinking.

\section{Analysis of critical thinking indicators for pretest and posttest results}

According to Ennis (1996), critical thinking consists of 5 indicators, including providing simple explanations, building basic skills, concluding, providing further explanations, and managing strategies and techniques. Critical thinking indicators used in this study are to provide simple explanations, build basic skills, and conclude. 
Someone who is said to think critically does not have to meet all the indicators of critical thinking. So to see a person's critical thinking ability, one of several indicators may be chosen according to the focus of the discipline to be studied (Pratiwi et al., 2016).

Indicators provide simple explanations requiring students to focus on questions, analyze arguments and ask and answer questions. Students learn to think critically gradually through habits that are carried out in the form of formulating problems and answering questions that require explanation (Leicester \& Taylor, 2010). The results of the data analysis of the pretest (pretest) and the final test (posttest) for indicators provide a simple explanation, which is presented in Table 4.

Table 4. Indicators give simple explanations

\begin{tabular}{ccccc}
\hline \multirow{2}{*}{ Category } & \multicolumn{2}{c}{ Replication 1 } & \multicolumn{2}{c}{ Replication 2 } \\
\cline { 2 - 5 } & $\begin{array}{c}\text { Pretest } \\
(\%)\end{array}$ & $\begin{array}{c}\text { Posttest } \\
(\%)\end{array}$ & $\begin{array}{c}\text { Pretest } \\
(\%)\end{array}$ & $\begin{array}{c}\text { Posttest } \\
(\%)\end{array}$ \\
\hline Very high & 0 & 42 & 0 & 46 \\
High & 0 & 36 & 0 & 29 \\
Medium & 0 & 14 & 0 & 23 \\
Low & 0 & 6 & 3 & 3 \\
Very low & 100 & 3 & 97 & 0 \\
\hline
\end{tabular}

Indicators of building basic skills require students to observe and consider the results of observations made. Critical thinking directs students to step out of self-deception by looking directly at these things from various angles and then evaluating them through a rigorous process of intellectual activity (Che, 2002). The results of the data analysis of the pretest and posttest for indicators of building basic skills are presented in Table 5.

Table 5. Indicators of building basic skills

\begin{tabular}{lllll}
\hline \multirow{2}{*}{ Category } & \multicolumn{2}{l}{ Replication 1 } & \multicolumn{2}{l}{ Replication 2 } \\
\cline { 2 - 5 } & $\begin{array}{l}\text { Pretest } \\
(\%)\end{array}$ & $\begin{array}{l}\text { Posttest } \\
(\%)\end{array}$ & $\begin{array}{l}\text { Pretest } \\
(\%)\end{array}$ & $\begin{array}{l}\text { Posttest } \\
(\%)\end{array}$ \\
\hline Very high & 0 & 23 & 0 & 57 \\
High & 0 & 10 & 0 & 26 \\
Medium & 0 & 1 & 0 & 11 \\
Low & 17 & 2 & 29 & 6 \\
Very low & 83 & 0 & 71 & 0 \\
\hline
\end{tabular}

The indicator of drawing conclusions means identifying the elements needed to draw conclusions from data, reports, principles, judgments, beliefs, or opinions (Zhou et al., 2007). In the indicator of drawing conclusions, there are still students who have not been able to draw conclusions properly and correctly, and students are more likely to only provide answers without giving conclusions. The results of the data analysis of the pretest (pretest) and the final test (posttest) for indicators to draw conclusions are presented in Table 6.
Table 6. Indicator draw conclusion

\begin{tabular}{ccccc}
\hline \multirow{2}{*}{ Category } & \multicolumn{2}{c}{ Replication 1 } & \multicolumn{2}{c}{ Replication 2 } \\
\cline { 2 - 5 } & $\begin{array}{c}\text { Pretest } \\
(\%)\end{array}$ & $\begin{array}{c}\text { Posttest } \\
(\%)\end{array}$ & $\begin{array}{c}\text { Pretest } \\
(\%)\end{array}$ & $\begin{array}{c}\text { Posttest } \\
(\%)\end{array}$ \\
\hline Very high & 0 & 11 & 0 & 6 \\
High & 0 & 39 & 0 & 40 \\
Medium & 0 & 14 & 0 & 20 \\
Low & 0 & 14 & 0 & 23 \\
Very low & 100 & 22 & 100 & 11 \\
\hline
\end{tabular}

In addition to descriptive analysis, this study also analyzed the results of $\mathrm{n}$-Gain testing and inferential statistical analysis. The results of the nGain test are presented in Table 7. The average nGain for replication class 1 is 0.68 , and for replication class 2 is 0.66 . Based on the average value of n-gain from the two classes, it is known that the effectiveness of the model used is still in the medium category. This indicates that there are still shortcomings in the application of the guided inquiry learning model. The drawbacks, among others, are that students are not familiar with the guided inquiry learning model, where the learning model requires students to be more active and independent. In fact, students are still accustomed to relying on teachers without students being directly and actively involved in the learning process.

Table 7. n-Gain test

\begin{tabular}{|c|c|c|c|c|c|}
\hline \multirow[b]{2}{*}{ Category } & \multirow[b]{2}{*}{ Class } & \multirow{2}{*}{$\begin{array}{c}\text { Number } \\
\text { of } \\
\text { samples }\end{array}$} & \multicolumn{3}{|c|}{ Gain index category } \\
\hline & & & $\begin{array}{c}\text { High } \\
(\%)\end{array}$ & $\begin{array}{c}\text { Medium } \\
(\%)\end{array}$ & $\begin{array}{l}\text { Low } \\
(\%)\end{array}$ \\
\hline Critical & $\mathrm{R} 1$ & 36 & 47.22 & 52.78 & 0 \\
\hline $\begin{array}{c}\text { thinking } \\
\text { ability }\end{array}$ & R2 & 35 & 42.86 & 57.14 & 0 \\
\hline
\end{tabular}

The average $n$-gain for replication class 1 is 0.68 and for replication class 2 is 0.66 . Based on the average $\mathrm{n}$-Gain value of the two classes, it is known that the effectiveness of the model used is still in the medium category. This indicates that there are still shortcomings in the application of the guided inquiry learning model. The drawbacks, among others, are that students are not familiar with the guided inquiry learning model, where the learning model requires students to be more active and independent. In fact, students are still accustomed to relying on teachers without students being directly and actively involved in the learning process.

Data on students' critical thinking skills were analyzed to determine whether the hypothesis was accepted or not. Inferential statistical analysis was conducted to see the consistency of the learning model used, namely the guided inquiry learning model. The first thing to do is to do a normality test. The normality test used is the Shapiro-Wilk test. The results of the normality test obtained a significant level of 0.006 for replication class 1 and 0.008 for replication class 2 . The value of the significance level of both classes showed a significant 
$<0.05$, indicating that the data were not normally distributed. One of the parametric test conditions is not met, so it cannot continue to test the hypothesis with parametric testing, so the alternative is to test the hypothesis with non-parametric tests.

Hypothesis testing in this study uses a nonparametric test, namely the Mann-Whitney test. Mann-Whitney is a two-sample independent test on non-parametric statistics which has the same purpose as the $\mathrm{t}$-test on parametric statistics (Suranto \& Apriliani, 2011). The test results obtained that the $\mathrm{Zh}$ value obtained is -0.076 , which indicates $\mathrm{H}_{0}$ is accepted. These results indicate that the average score of students' critical thinking skills in replication class 1 is the same as in replication class 2 .

Based on the description above, it can be seen that the guided inquiry learning model has a good impact on students' critical thinking skills. The guided inquiry learning model can improve students' critical thinking skills seen from the relatively significant data of replication class 1 and class 2 replication. The results of this study are supported by several studies conducted by Fajariyah et al. (2016) regarding the application of the guided inquiry learning model to improve students' critical thinking skills with the results of the research that students' critical thinking skills increased where in the first cycle it was $54 \%$ and the second cycle was $94 \%$. Muharamiah et al. (2016), regarding students' critical thinking skills using guided inquiry learning models, experienced an increase in critical thinking skills by $100 \%$ in the skilled category.

\section{Conclusions}

Based on the results of research data analysis, it can be concluded that students' critical thinking skills with the application of guided inquiry learning models on colloidal system material can improve the critical thinking skills of students in class XI SMAN 3 Palu.

\section{Acknowledgments}

The authors would like to thank the class XI chemistry teacher at SMAN 3 Palu and the students in class XI MIA 1 and class XI MIA 3 at SMAN 3 Palu who helped the author so that this research went well.

\section{References}

Aningsih, A. (2018). Kemampuan berpikir tingkat tinggi pada pendidikan agama Islam siswa kelas $X$ SMK Muhammadiyah 1 Purwokerto ditinjau dari prestasi belajar. Unpublished Thesis (S1) Purwokerto: Universitas Muhammadiyah.

Banchi, H., \& Bell, R. (2008). The many levels of inquiry. Science and Children, 46(2), 26-29.

Budiartini, N. L. O., Arcana, I. N., \& Margunayasa, I. Gd. (2013). Pengaruh model pembelajaran inquiri terbimbing terhadap kemampuan berpikir kritis IPA siswa kelas V di SD 7 Datah. Mimbar PGSD Undiksha, 1(1), 1-10.

Che, F. S. (2002). Teaching critical thinking skills in a Hong Kong secondary school. Asia Pacific Education Review, 3(1), 83-91.

Ennis, R. H. (1996). Critical thinking. New Jersey: Printice-Hall, Inc.

Fajariyah, N., Utami, B., \& Haryono. (2016). Penerapan model pembelajaran inkuiri terbimbing untuk meningkatkan kemampuan berpikir kritis dan prestasi belajar pada materi kelarutan dan hasil kali kelaritan siswa kelas XI SMA Al Islam 1 Surakarta tahun ajaran 2014/2015. Jurnal Pendidikan Kimia, 5(2), 8997.

Fardani, R. N., Ertikanto, C., \& Suana, W. (2016). Pengaruh kemampuan berpikir kritis pada penggunaan modul berbasis inkuiri terhadap hasil belajar. Jurnal Pembelajaran Fisika, 4(2), $1-10$.

Heong, Y. M., Othman, Yunos W. B. Md., J. Bin, Kiong, T. T., Hassan, R. Bin, \& Mohamad, M. M. B. (2011). The level of Marzano higher order thinking skills among technical education students. International Journal of Social Science and Humanity, 1(2), 121-125.

Ijirana. (2016). Model pembelajaran berbasis keterampilan metekognitif (model PBKM) untuk meningkatkan kemampuan pemecahan masalah pemahaman konsep kimia mahasiswa pendidikan kimia. Unpublished Dissertation. Surabaya: Universitas Negeri Surabaya.

Kipper, H., \& Ruutmann, T. (2013). Teaching for understanding in engineering education. International Journal of Engineering Pedagogy, 3(1), 55-63.

Leicester, M., \& Taylor, D. (2010). Critical thinking across the curriculum. New York: McGraw-Hill Open University Press.

Muharamiah, T., Hairida, \& Rasmawan, R. (2016). Keterampilan berpikir kritis siswa menggunakan model pembelajaran inkuiri terbimbing pada materi asam basa. Jurnal Pendidikan dan Pembelajaran, 5(06), 1-13.

Peraturan Menteri Pendidikan dan Kebudayaan. (2013). Implementasi kurikulum. Retieved 22 July, 2017, from https://www.kemdikbud.go.id/kemdikbud/do kumen/Paparan/Paparan\%20Mendikbud\%20 pada\%20Workshop\%20Pers.pdf.

Pratiwi, F, A., Hairida., \& Rasmawan, R. (2014). Pengaruh penggunaan model discovery learning dengan pendekatan saintifik terhadap keterampilan berpikir kritis siswa SMA. Jurnal Pendidikan dan Pembelajaran Khatulistiwa, 3(7), 1-16.

Pratiwi, J. A., Mirza, A., \& Nursangaji, A. (2016). Kemampuan berpikir kritis aspek analysis siswa di sekolah menengah atas. Jurnal Pendidikan dan Pembelajaran Khatulistiwa, 5(12), 1-12. 
Zhou, Q., Wang, X., \& Yao, L. A. (2007). A preliminary investigation into critical thinking of urban Xi'an high school students. Frontiers of Education China, 2(3), 447-468.

Rofiah, E., Aminah, N. S., \& Ekawati, E. Y. (2013). Penyusunan instrumen tes kemampuan berpikir tingkat tinggi fisika pada siswa SMP. Jurnal Pendidikan Fisika, 1(2), 17-22.

Salbiah. (2017). Profil keterampilan berpikir kritis siswa menggunakan pembelajaran discovery il.nquiry pada konsep koloid. Jurnal Tadris Kimiya, 2(1), 109-115.

Sanjaya, W. (2009). Strategi pembelajaran berorientasi standar proses pendidikan. Jakarta: Kencana Media Group.

Suprihatiningsih, J. (2013). Strategi pembelajaran teori dan aplikasi. Yogyakarta: Ar-Ruzz Media.
Suranto, \& Apriliani, D. (2011). Analisis perbedaan mental wirausaha mahasiswa dengan non parametrik. Jurnal Ilmiah Teknik Industri, 10(1), 35-41.

Suyanti, R. D. (2010). Strategi pembelajaran kimia. Yogyakarta: Graha Ilmu.

Trianto. (2010). Mendesain model pembelajaran inofatif progresif. Jakarta: Kencana.

Wati, R., Rusmansyah., \& Sholahuddin, A. (2014). Meningkatkan kemampuan berpikir kritis dan hasil belajar siswa kelas XI IPA 2 SMA PGRI 4 Banjarmasin pada konsep sistem kooid melalui model problem based learning. Quantum: Jurnal Inovasi Pendidikan Sains, 5(2), 20-31. 